\title{
CULTURAL DIVERSITY AND ITS PSYCHOLOGICAL IMPACTS IN BHARATI MUKERJEE'S "THE HOLDER OF THE WORLD"
}

\author{
Dr.G.RENUKA DEVI M.A.M.Phil ., PhD., \\ Assistant Professor of English, \\ Devanga Arts College, \\ Aruppukottai
}

\begin{abstract}
:
Bharathi Mukherjee's "The Holder of the World" is the tale of Hannah Easton, a remarkably unique woman born in the seventeenth century, who is inquisitive, and how her life journey takes her from the forests of Massachusetts to the palace of an emperor in India. This also tells the story of Beigh Masters, an 'assets hunter' born in mid-twentieth-century New England who is hunting for the most prized diamond, 'The Emperor's Tear' of
\end{abstract} Aurangazeb. During the search, she stumbles upon the scattered record of Hannah's life, who happens to be a distant relative. Tracing the threads of her life in bits and pieces, she becomes enraptured by the trials and tribulations of Hannah, who ends up the loving mistress of Raja Jadav Singh, and fights for his life during the religious war, ends up saving his life, fights a Muslim general and had to plead for mercy before the Emperor Aurangazeb himself. She barely survives another war and comes in possession of the invaluable gem. Bharathi Mukherjee's words paint an elaborate picture of the history of seventeenth-century India, a romantic view of interpersonal relationships, and science fiction narrated through Beigh.

\begin{abstract}
Keywords: $\quad$ Cultural Diversity,
Psychological, relationships, etc
\end{abstract}

Immigration results in an identity crisis; an individual loses one's own identity on alien soil. He becomes a non entity. Simply identity means the distinguishing character or personality of an individual. Identity is what a person is and always has been. It is also a mark of individualism. It becomes the stamp or hallmark of a person, at other times; it can be a habit or a customary behavior, or characteristic of an individual. The Feminist critic, Jill Johnston states that "Identity is what you can say you are according to what they say you can be" (71). An individual needs to maintain an identity. It assures one's life and career in the face of overwhelming odds. A crisis in one's identity arises when one is unstable and unbalanced in one's self and about his/her surroundings. The state of identity confusion leads to a heightened sense of alienation, immigration, and exile. Webster's Dictionary defines identity crisis as a "Psychological confusion and maladjustment that arises especially in adolescents when unable to attain psychological identification because of conflicting demands and pressures 
anomie"(563). An immigrant suffers such a crisis more than others. Though identity crises can occur within the same atmosphere; immigration adds an impetus for further disintegration. This pathetic search for an identity is consciously and unconsciously experienced by an immigrant in every progressive stage of his /her life.

Indian women writers writing in the radical twenties dealt with various contemporary social issues and concerns related to women. From female infanticide, their writings range through a wide spectrum of issues like dowry, rape, violence against women, girl child abuse, marital incompatibility, and so on to name a few. However, one of the motifs that are recurrent in Indian Women Writers is immigration and the problems related to an identity crisis, cultural shock, racial prejudice, and segregation, and so on. Numerous Indian diaspora women writers, who staying abroad, also deal with the theme of immigration.

Thus, immigration can be considered a journey for the immigrant in many other ways. Shakrukh Hussainays; "Psychoanalysis has identified the journey as a voyage of self - discovery, which provides the 'missing parts of the travelers' experience and helps identify her individual needs and desires" (20). Immigration has become the major area of concern for many modern writers. It has, at the same time, become a necessity and also an inevitable fact of the twentieth century. East-West encounter forms an important area of concern in the works of Kamala Markandaya, who has established an intimate relationship with the west. She is aware of her vulnerability as an immigrant. Her perception perhaps is conditioned by her bicultural existence. Ruth Prawer Jhabvala is a European writer who lived in India for a considerably long time. Anita Desai is another such personality among the diaspora group of writers. Hence, the experience of the diaspora writer is itself proof if one tries to trace the autobiographical instances in their workings.

Homi J. Bhabha in The Location of Culture argues that cultural translation is a part of the spatial histories of displacement. He argues that culture is both transnational and translational. It is transnational because contemporary postcolonial discourses are rooted in specific historical situations of displacement. It is transnational because it makes "The question of how culture signifies, or what is signified by culture, a rather complex issue" (172). In Holder, Mukherjee translates culture by creating a virtual space and transcending time. For both Venn and Beigh, history is a commodity. Nalini Iyer in "American Indian: Metaphors of Self in Bharathi Mukherjee's "The Holder of the World" observes: "The story of Hannah retold by Beigh and present in fragments in Hannah's voice focuses on the transnational and translational aspects of culture and location. At first, Hannah's history is that of spatial displacement" (36). Hannah breaks racial and geographic boundaries. She shuttles between two cultures - American/ Puritan and Indian. Nalini Iyer further relates: "In presenting Hannah's identity as transcending 
International Journal of Trends in English Language and Literature (IJTELL) An International Peer-Reviewed English Journal; Volume-2, Issue-3; 2021 $\underline{\text { www.ijtell.com }}$ Impact Factor: 5.144(SJIF)

ISSN: $2582-8487$

geographic space, Mukherjee examines location as ideological space and interrogates how race and gender constitute a fluid rather than a fixed identity. Hannah's fluid sense of race and ethnicity signified by her constant Hannah Easton to Hannah Fitch to Hannah Legge to Salem Bibi to Mukta and Bhagmati's similar renaming - from Bindu Bashini to Bhagmati to Hester - suggest that one's identity is constrained by the narrative that one constructs and the actual experiences that one undergoes" (37). Holder may be taken as an alternative history that connects and reconnects the imaginative relations between the immigrants in India and the natives of India like Bhagmati and the Raja Jadav Singh.

Marriage to Gabriel, however, fails to fulfill her. The romance of the East he conveyed through his stories proves to be as distant from her life as a house-bound wife in England. Hannah used to keep diaries. It is from one of her writings, Beigh comes to know of their sexual connectedness. Beigh details: "Her written record is one long chronicle of discoveries, her curiosity extends to every branch of knowledge she ever had contact with. Except for sexual love, at least with Gabriel Legge. They lived together on Stephney fewer than three months before he shipped out the first time" (HW 76). When the news of Gabriel Legge's death arrives loudly. She feels dejected; however, she is proposed to by a man called, Hubert who has proposed her to marriage. "Hubert was not disturbed by her widowhood. He meant Cambridge, where she could find lodging and employment as a governess. She suspected that he also meant marriage, after a decent interval, but the creditor his shame, it was never mentioned" (86). Then Gabriel has emerged as an East India Company officer. This time, she decides not to let him leave her behind for she has become "Tired of waiting at home, of not bestirring herself in the rich new world opening out at every hand. Even pouches of diamonds did not seem sufficient compensation for idleness" (86). The life of romance she has hungered for seems to be possible. So, she decides to accompany Gabriel to India. Although Hannah arrives in India and is ready to immerse herself in the sights and sounds of the Coromandel Coast, she finds her life and herself confined to the petty and hierarchical world of East India Company officials and their wives. Just as the New England Puritans had separated themselves from the American Indians, the English in India seems to have fenced themselves off from the natives of India. However, "She was alert to novelty, but her voyage was mental, interior, Getting there was important, but savoring the comparison with London or Salem, and watching her life being transformed, that was the pleasure. She did not hold India up to inspection by the lamp of England, or of Christianity, nor did she aspire to return to England upon the completion of Gabriel's tour" (104).

Hannah keeps looking for opportunities to transform herself in contact with Indians. She remembers her mother and her mingling with Nimpucs. Beigh relates" "If she judged the world from a single unassailable place, it might have been from a forest in Brookfield, 
International Journal of Trends in English Language and Literature (IJTELL) An International Peer-Reviewed English Journal; Volume-2, Issue-3; 2021

before the expulsion from that New World Eden. In India, she is frustrated in her quest for self-fulfillment by her husband, Gabriel, who neglects her. She spends Her days in a dream of sensuality" (132). She becomes a woman to be sexually awoken. The one occasion that Beigh Masters could manage to record Hannah's moment of sexual bliss or awakening by connecting herself with her husband Gabriel is after the Chief Factor Cephus Prynne's enragement to Gabriel by casting aspersions on Hannah's encounters with Indian merchants. Enraged, Gabriel arranges for the murder of Chief Factor Cephus Pryne. Delighted by her husband's gallantry, Hannah rewards him by making love to him one night on a beach. However, it is an unusual love affair. Immediately after this bliss, Gabriel deserts her forever. However, "The Coromandel had started something as immense as a cyclone deep inside her body and mind. To let Gabriel go was also to let herself expand" (163). Then Gabriel returns with his Indian mistress. Later, she hears about his drowning in a cyclone in the Bay of Bengal.

Hannah finally enters the world of her exotic dreams along with Bhagmati. She becomes the guest of the Raja, Raja Jadaw Singh, the Rat of Coromandel in Panpur fort. Hannah realizes for the first time in her life: "That Panpur had a fort, a courtyard with fountains, landscaped gardens with canals and monarch capable of inspiring apparent devotion made her realize how myopic had been her life in Fort ST.SEBASTIAN" (218).
Even Bhagmati is no longer an Indian maid. She has been born with the name Bindu. She had fallen in love with the Englishman Henry Hedges. "She trusted absolutely Hedge's ability to keep foreignness at bay, just as she trusted Raja Jada Singh to keep her safe. But when Hannah had offered to take her to England, she had refused to go"(224). Hannah now enters the beautiful world of her desires that she had been dreaming of for many years. Commenting on her entry into the exotic, sensual world of Raja Jadav Singh, Fakrul Alam in Bharati Mukherjee avers: "No doubt Rebecca Easton's phase into the arms of her Nipmuc Indian lover had made her similarly heady and disdainful of restraint and reason, for Hannah now abandons herself to the Indian king" (128). It is love at first sight. Beigh Masters comes to realize this by reading her Memoirs. Beigh admits: "Years later, in memories, she made a brief cryptic reference to what came to pass between the lion of Devgad and the Brookfield orphan. An angel counseled me, a fantasy governed me: 'Biss descends on the derangers of reason and intellect" (KW 228).

But the Raja is in the middle of a war with the emperor Aurangzeb. Aurangzeb has sent a huge army to destroy and seize the Hindu King. Raja Jada Singh. When the king is wounded by Aurangzeb's army, Hannah enters and braves into the battlefield to rescue the fallen Raja. She is then captured by Mughal General. However, she manages to kill the General and rescue the wounded Raja and bring him back to his palace. When the Raja is revived, he rejects her 
proposal to run away from the feud with the emperor. Even her disclosure that she is carrying his child will not defer/deter him from going for a battle once again to avenge the wrong done to his father by Aurangzeb. So Hannah crosses the battle line to meet and persuade Aurangzeb not to fight with Raja Jadav Singh. Aurangzeb is impressed by Hannah's determination but he will not be moved from his intention to annex the Hindu kingdom with the Mughal kingdom. In the final battle between the Raja Jadav Singh and Aurangzeb, the Raja Jadav Singh is killed and Hannah is allowed to go back to her place. She has to go back to Salem, giving birth to Pearl on a ship in the Atlantic Once in Salem, she finds her mother Rebecca Easton. In the end, with her mother and daughter, she begins to live puritan community. Beigh Master relates.

The quest for cultural connectedness in Holder also results in sexual awakening with the other - the other lover. The same theme has been handled by Mukherjee in Wife, "The Lady from Lucknow" and "A wife's story". Mukherjee also creates women who break their moribund marriage to bliss or the promise of a fulfilled life through a relationship with an alien. In Wife, Dimple has a sexual liaison with the foreigner, Milt Glasser and even Jasmine has many sexual awakenings with aliens and strangers. Fakrul Alam in Bharathi Mukherjee concerns that "Although Beigh has experienced the ash of sterile relationships and is relishing happiness with Venn. The sexual awakening through an 'other' is conveyed chiefly through Hannah Easton's Life that is, the main theme to us of The Holder of the World is in the romance of Hannah's relationship with an Indian Raja" (125). Even at the beginning of the novel, Beigh's scrutiny of the Salem Bibi miniatures in the Massachusetts Museum hints that Hannah is a woman destined for contact with an 'other'. It is detailed by Beigh.

References:

Mukherjee, Bharathi, The Holder

of the world 1993 Newyork:

Fowcott Books,

1993

Nish, Sushelia Home Truths:

Fiction of the South Asian Diaspora in Britaiu Basigstoke :

Palagrace 2012

Naikal, Busavaraj .ed, Indian

English Literature NewDelhi: Atlantic

Publishers 1994

"Introduction"

Bharathi

Mukherjee critical Perspectives ed Emmanuel. S.Nelson. 